\title{
Wall Street remains bearish on value of genome project
}

Washington. Investors are unimpressed by last week's announcement (see Nature 358, 95 ; 1992) that a venture fund is starting a $\$ 70$-million company to commercialize genome project research. Unresolved patent issues, limited markets for gene-based diagnostics and the slow progress of technology still make the genome project a risky prospect in their minds, despite widespread recognition of the long-term potential. Although the picture could change dramatically with a favourable decision by the US Patent Office on cDNA patents or the discovery of a key gene, few investors are ready to gamble their money on its prospects.

The Institute for Genomic Science and Human Genome Science Inc. - the research and marketing arms of the new company - will initially focus on sequencing cDNA, copies of genes that are expressed in the human body. Analysts expect that to be one of the few marketable areas of genome research in the near term.

Although researchers do not know the function of most of the genes that match the cDNA sequences, they can at least tell investors that the area is worth pursuing. The same cannot be said about DNA sequencing in general, where the chance of identifying a disease gene or other useful DNA regions is orders of magnitude lower and the slow pace of sequencing technology development is most keenly felt.

It may be that there is room for only one big company. J. Craig Venter, the former US National Institutes of Health (NIH) researcher around whom the new venture has been founded, may finish sequencing most of the human cDNA library in a year or two. As have many of those sequencing cDNA, including British government scientists and industrial groups, Venter has either filed patents for his sequences or has not yet released them into the public domain.

But Venter's venture may have the cDNA exploration field to itself at present. Few outside investors are willing to put money into further research on cDNA sequences to learn their function, for example - if they are not sure of owning the product.

However, if bare cDNA sequences turn out not to be patentable - as the White House is now predicting (see below) anyone would be free to hunt for the biological function of cDNA sequences. Although Venter's group may have a headstart, there are as many as 100,000 genes to explore, more than enough for several companies. Without cDNA patents to muddy the waters, "it's off to the races", says M. James Barrett, president of the Maryland-based Genetic Therapy Inc.

Beyond cDNA research, the best pros- pects for near-term commercial investment in the genome project appear to be in genebased diagnostics and those interested in the project as a market. At an estimated $\$ 10$ billion a year, the US diagnostic market is huge. But prenatal and parental tests for genetic diseases make up less than one per cent of that, says John Teipel, an analyst with the New-York-based Wilkerson Group.

As the cystic fibrosis (CF) case proved, finding a gene does not create a major market overnight. Three years after the discovery of the gene, prenatal and parental CF screening tests are just appearing and the market is not expected to exceed $\$ 10$ million in the near term. "We never felt it was enough to base a company on", says Anne Di Sante, director of the intellectual property office at the University of Michigan, where the gene was discovered. "It's just a gene - not a delivery mechanism for gene therapy."

Although the genome project is expected to turn up many other genes associated with genetic disease during its 15-year life, converting those genes into products - using anything from genetic therapy to therapeutics based on expression products - is a long and complicated process, something the biotechnology industry has learned the hard way. "Scientists may be convinced that it's good science, but that doesn't necessarily translate into good business", says Steven Burrill, a biotechnology expert with the San-Francisco-based accounting firm of Ernst \& Young.

For the moment, the best bet for investors is companies with products stemming from the genome project itself. Several computer companies, including IBM, are funding genome informatics research in the hope of sharing what is expected to be a major market in processing genome information. Other investors have their eye on the $\$ 3$ billion the US government is expected to spend on the project over its lifetime.

Frederic Bourke, the wealthy entrepreneur whose attempt to start a sequencing company earlier this year triggered an international controversy (see Nature 355, 483; 1992), says he intends to go ahead with his project despite failing to recruit several prominent researchers. Bourke is considering an investment of $\$ 50-\$ 60$ million to start a company that would operate at first under contracts and grants from the US government and industry.

But he too warns that the genome project is not yet a sure investment, and that it is easy to back the wrong technology or people. Even if scientists agree that the time is ripe for a large sequencing operation, says Bourke, "it's got to be economically viable. I'm not Fort Knox." Christopher Anderson

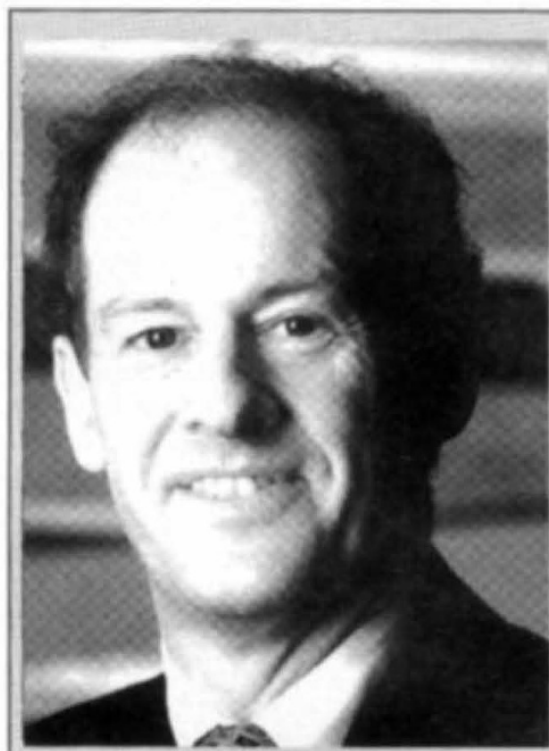

Bromley says no to treaty.

US rules out gene patent treaty

Washington. The chief US science official said last week that the United States will abide by its controversial decision to file applications for patents on gene fragments and will not pursue an international treaty on the issue. D. Allan Bromiey, science adviser to the president, said that the White House is confident that the US patent office will reject applications for more than 2,000 unknown gene fragments and, therefore, that no policy decision is needed.

Until the patent office makes its ruling, Bromley said, the United States will continue its interim policy of filing patents for fragments of expressed genes, even though their function is unknown. But he expects a ruling much sooner than the usual two or three years the patent office takes for routine applications. In the meantime, Bromley said, the cost to the US National Institutes of Health (NIH) and to companies that are following NIH's lead is "trivial" compared with the overall cost of the project and was not a factor in the administration's decision to file for patents.

Bromley said that a proposal by Britain, France and Japan for an international treaty that would forbid patents on such uncharacterized gene fragments would be like "using an elephant gun to kill a butterfly". Patent offices in Europe and Japan are thought to be even less likely than the US patent office to approve the NIH application, and Bromley believes that the issue can be resolved without the need for a policy confrontation. 